Portland State University

PDXScholar

1976

Historical Aspects of Indian Life and Their Effects on the Urban Indian

Ramona Cliff

Portland State University

Follow this and additional works at: https://pdxscholar.library.pdx.edu/open_access_etds

Part of the Social Work Commons

Let us know how access to this document benefits you.

Recommended Citation

Cliff, Ramona, "Historical Aspects of Indian Life and Their Effects on the Urban Indian" (1976).

Dissertations and Theses. Paper 1908.

https://doi.org/10.15760/etd.1907

This Thesis is brought to you for free and open access. It has been accepted for inclusion in Dissertations and Theses by an authorized administrator of PDXScholar. Please contact us if we can make this document more accessible: pdxscholar@pdx.edu. 


\title{
HISTORICAL ASPECTS OF INDIAN LIFE AND \\ THEIR EFFECTS ON THE URBAN INDIAN
}

by

RAMONA CLIFF

\begin{abstract}
A practicum submitted in partial fulfillment of the requirements for the degree of
\end{abstract}

MASTER OF SOCIAL WORK

Portland State Unfversity

1976 
TO THE OFFICE OF GRADUATE STUDIES AND RESEARCH:

The undersigned approves the practicum of

Ramona A. Cliff presented August 11, 1976.

Nancy M. Koroloff, Assistant Professor, School of Social Work 
Purpose of the Study . . . . . . . 1

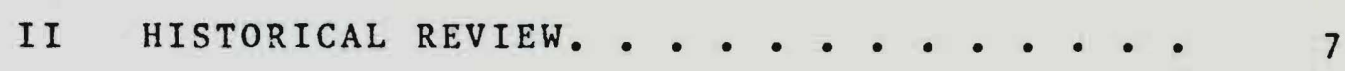

The Need for the Study . . . . . . 7

The Unique Role of Indians in American Society: Character of the American Indian. . . . . . . 8

Indian Treaties 9

Indian Claims Comission $\quad 11$

Indians as a Problem in the Territorlal Struggle Over Land

Decline In Indian Population 12

Early U. S. Indian Policy 13

Indian Reservations $\quad 14$

Government Policy for Indian Reservations 15

Termination Policy 15

Indian Migration to Urban Areas 16

Relocation Program 16

Federal Relationships of Urban
Indians

Service Needs of Urban Indians. . . . 20

Data on Human Service Needs of
Urban Indians

Summary . . . . . . . . . . . 24 
III DESCRIPTIONS FOR LOCAL SYSTEMS. . . . . . 29

Urban Indian Program. . . . . . 29

Bureau of Indian Affairs. . . . . 30

Indian Health Services. . . . . . 31

Native American Rehabilitation
Association................. 33

other Groups... . . . . . . . 33

Summary . . . . . . . . . . 34

IV METHODOLOGY : DESIGN AND PROCEDURE • • 36

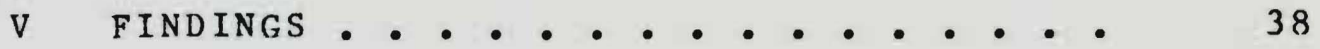

Characteristics of the Tribal Profile........... .

Where the Subjects Came From and Why They Came to Portland. . . . 40

Quality of Services. . . . . . 41

CONCLUSION

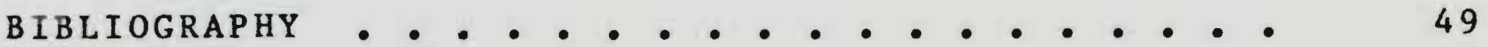




\section{CHAPTER I}

\section{INTRODUCTION}

Purpose of the Study

The purpose of this study is to explore one aspect of American Indian life: the personal situations and polftical implications of the American Indian residing in an urban setting. Numerous studies have been conducted with minority populations residing in urban areas in an effort to direct attention to the social phenomena that affect these minority groups. Newman's American Pleurism offers several definitions of the term "minority group" that soclologists have employed in the past. One such definition most relevant to this study was first formulated by Louis wirth:

We may define a minority group as a group of people who, because of their physical or cultural characteristics, are singled out from others in the soclety in which they live for differential and unequal treatment and who therefore regard themselves as objects of collective discrimination. 1

Indians are a "socfety" living within the dominant society of this country, whether the location is on a reservation or within an urban area. Levine, in The American Indian Today, states:

They are a fair-sized minority group.. . who are living in the general culture but have a strong sense of ties to Indian ancestry. 2

Levine's points are: number one, the Indians are not vanishing; number two, Indians are not alike; number three, Indians for the 
most part do not like to be associated with the Clvil Rights Movements; number four, not all Indians live on reservations and not all are in the same economic boat; and number five, Indian people do not form a political bloc in the way other minority groups do. 3

Historlcally, the American Continent was inhablted by aboriginal peoples who lived in a primeval state that was 1deal to their sustenance and the perpetuation of thelr race. Anthropologists support the findings of man's antiquity in the Americas: as an example, Farb, In Man's Rise to Civilization, 4 presents the hypothesis of aborlginal evolution in the Americas. Farb presents evidence that aboriginal American people represent one of the world's most lsolated populations. He supports his presented hypothesis with evidence of genetic traits such as blood type, headshape, and fingerprints, that these clues to an aboriginal race are influenced neither by environment or diet. With the exception of the Eskimo and the Aleut Indlans, the blood groups of aboriglnal Amerlcans are remarkably unfform, so much so that the aboriginal Amerlcans have been placed, at least by one anthropologist, In a separate race, distinct even from the Astan Mongo1o1ds. The American Indian ls unfque because his particular cluster of several blood trpes and other physlcal trafts are not found in the same combinations in other races around the world.

Vine Delorla states, In fod Is Red, that there is reluctance of scholars to consider the possiblitty of pre-Columbian 
visits to the Western Hemisphere and further, that there is evidence that this continent was visited by numerous expeditions prior to the arrival of Columbus. 5

Elementary school taught us that American History began with the discovery of the New World by Columbus in 1492. Upon exploration and colonization of the New World by the immigrants from the old World, mostly European, the aboriginal American, now called the American Indian, and even more recently, the Native American, was pushed ever westward upon each encroachment and settlement of his aboriginal territories. Out of this antiquity and history was born the American Indian "reservation." Through centuries of historically racial conflict and controversy, besieged by exploftation, colonfzation, and treaties with the new immigrants, the aboriginal people became to be known as the Indians who live on "reservations."

Throughout the history of the settlement of America, upon each westward surge of the European Immigrant, "treaties" were signed with the natives who dominated the territories, as each territory was settled. With the signing of treaties many of the native tribes were offered exchanges of land holdings and other services deemed necessary to their livelihood: food, clothing, health care, and the opportunity to assimflate into the mainstream of American life--"the great American melting pot."

In a traditional way of life before settlement by the European Immigrants, the aboriginal people were joined together by tribal units, characterized by genetic, cultural, and 
blological bonds. These tribal units maintalned themselves within specific areas on the American Continent. These entfties are known as tribal territories. Within each tribal territory the tribal units lived mostly a nomadic life-style that was governed by the forces of nature, relative to the sustenance of the tribal units' livelihood.

From this historical overview we can see that the American Indian possesses a diverse and complex nature: the concepts of "high mobility" and "permanent setting" applied to the American Indians' earlier lifeways both one and at the same time. As the Indians were settled on "reservations" the concepts of "permanent setting" were in force, both by the demands of the treaties and the complexities of the laws of early America. In general many Indians resisted reservation settlement throughout the American historical eras. The treaties and the laws of the land prevented the Indians from functioning in the lifeway of mobility that they were accustomed to, and discontent of reservation life became an imminent factor that was to inevitably affect and alter the American Ind ians' $11 \mathrm{fe}$.

At this point in the history of the Indians, government legislative action further complicated matters by enjoining them to migrate to cities and towns in order that they become more acculturated with the dominant soclety. In so doing, Indian lifeways were altered from the traditional hablt of life in a tribal unit, which is an extended family unit, to the 
nuclear family unft prevalent in the urban centers of the country. Here again the concept of "high mobllity" fractures the attempts of the Indian family's venture into a new way of life, for as a culturally characteristic trait the Indian is continually drawn back to the tribal lifeway of the extended family unit. Thus, the Indian may migrate to and from the reservation often, and for many different reasons: 11ke cultural and social events that can be family feasts, festivals, celebrations, pow-wows, rodeos, and religious rites that are indigenous to Indian life, and other reasons like famlly funerals. Additionally, many Indians are drawn to their reservations for political and economic reasons, such as tribal elections and other kinds of tribal affafrs.

The study is definitive in structure, since the author felt the need to explore the historfcal aspects of the Indians' migration to urban areas. The study presents a detalled review of the Indians' history, relative to their relationship to the dominant society.

The study will first present a historical review of American Indian life, and second, it will present the findings of an empirical study that was done with one group of urban Indians, to explore thefr characteristics and human service needs. 
CHAPTER I

FOOTNOTES

$1_{\text {William M. Newman, American Pleurlsm, A Study of }}$ Minority Groups and Social Theory, (New York: Harper \&

2 Stuart Levine and Nancy 0 . Lurie, The American Indian Today (Baltimore: Penguin Books, Inc., 1972), pp. 10-15.

${ }^{3}$ Ibid.

${ }^{4}$ Peter Farb, Man's Rise to Civilization As Shown By the Indians of North America From Primeval Times to the Coming of the Industrial State (Dutton, New York: 1968), p. 277 .

${ }^{5}$ Vine Delorla, Jr., God Is Red (New York: Del Publishing Co., 1973), p. 126 . 


\section{HISTORICAL REVIEW}

\section{The Need For the Study}

The concept of this study came about as the result of a number of interrelated factors, relative to the American Indian who resides in an urban setting. The author felt the need to broaden the scope of knowledge pertaining to Indians who reside in urban centers. Sorkin, In American Indians and Federal Aid, states:

Probably less socio-economic information exists about the Indian than about any other minority group in the Unfted States.1

The scope of the Sorkin statement can only be appreciated by looking at the span of years covered by the published 11 terature pertalning to the American Indian. There is a vast amount of literature written about them, mostly from the historical perspective of the academic world. Deloria, noted Indian spokesman of today, in God is Red, presents a chapter titled, "Indians of America." He comments on some of the literature written about American Indians, including noted works of fiction. He states:

In an effort to respond to the increasing market for books about Indlans and by Indians, a number of 
publishers eagerly sought out manuscripts on Indians by both Indian and non-Indian authors... Until this development, Indian 1 iterature stereotyped the Indian condition, thus hampering rather than helping the examination of the state of contemporary Indfan affairs. The field of literature on American Indians is totally unlike any comparable field of American study. It breaks down into a number of easily categorized viewpoints which when taken together reveal much more about the conception of America held by the reading public than about American Indians, past and present. A review of the types of 1 iterature avallable on American Indians indicates that insofar as the Indlan activists belleved (and still belleve) that they could tap the wellspring of hidden white sympathy, the task was almost hopeless and futile.2 Deloria's argument is that other flelds of literature successfully enable people to empathize with conditions and cultural varlances but that literature about Indians falls to evoke sympthy for them.

The Unique Role of Indians in American Soclety: Character of the American Indian

The character of the American Indian is generally drawn in a derogatory manner. In the evolution of civilization in the "New World", the American Indian has been placed in a unique role wthin the dominant American soclety. Indians have been seen as an invisible counterpart of the dominant American society since the time European explorers first set foot on the American continent. Since the time of written and recorded history in America, the aboriginal inhabitants have been portraved by these historlans and recorders as flerce and uncivilized peoples. ${ }^{3}$ Farb, In Man's Rise to Civilization, gives a chronological study of prehistoric Indian cultures and presents relevant information on cultural deviations. ${ }^{4}$ Farb's study is recognized by academicians and Indians alike as one of the most relevant pleces of literature 
about Indians. 5

The history of relations between the European Immigrants and the aborigfnal inhabitants, the Indian, has been called disgraceful by scholars who have studied American history and Ind 1 ans.

During the late sixteenth century and the early seventeenth century, early American territorial conquest of abor 1 ginal lands was negotiated by wars between England, France, and Spain. At that time France and Spain possessed territorial claim to parts of the American continent. England was successful in claiming the American territories through war and land purchases. A major land purchase was the Louisiana Purchase of 1803. Indian historians today have legitimate questions concerning the legality of the land purchase. Thomas Jefferson, as United States President, proposed a constitutional amendment to legitimatize the purchase and answer the practical and philosophical problems it posed. Jefferson's proposed amendment dealt largely with the relationship between the United States and Indian nations. 6 Jefferson recognized that France's title to the West (The Loulsiana Territory) did not apply to Indian lands, and that purchase by the United States could not imply federal ownership of Indian land. Jefferson's major point was recognition of Indian soverefgnty and land title in the West. 7 Indian Treaties. In the conquest of the "New World" by European colonists, the aboriginal peoples were not treated as soverelgn nations, but were viewed as obstacles in the path of settlement and industrialization of the New World. The govern- 
ment of the early United States negotiated with Indians for territorial rights by legislative agreements, treaties, and at times, leglslative acts and amendments. In 1869, treatymaking policy was questioned when Indian Commissioner Ely S. Parker made this recommendation to the federal government.

- - A treaty involves the idea of a compact between two or more soverelgn powers, each possessing sufficient authority and force to compel a compliance with the obligations incurred. The Indian tribes of the United States are not sovereign nations, capable of making treaties, as none of them have an organized government of such inherent strength as would secure a falthful obedience of its people in the observance of compacts of this character. They are to be held to be wards of this government, and the only title the law concedes to them to the lands they occupy or claim is a mere possessory one. But, because treaties have been made with them, generally for the extinguishment of their supposed absolute title to land inhabited by them, or over which they roam, they have become falsely impressed with the notion of national independence. It is time that this idea should be dispelled, and the government cease the cruel farce of thus dealing with its helpless and ignorant wards. Many good men, looking at this matter only from a Christian point of view, will perhaps say that the poor Indian has been greatly wronged and illtreated; that this whole country was once his, of which he has been despolled, and that he has been driven from place to place until he has hardly left to him a spot where to lay his head. This indeed may be philanthropic and humane, but the stern letter of the law admits of no such conclusion, and great injury has been done by the government in deluding this people into the belief of their being independent soverelgnties, while they were at the same time recognized only as its dependents and wards. As civilization advances and their possession of lands are required for settlement, such leglslation should be granted to them as a wise, 1 iberal, and fust government ought to extend to subjects holding their dependent relation.8

Commisioner Parker's recommendation is an example of the paradoxical position the federal government assumed in their policymaking relationship with the Indians. 
Much of the Indian lands were taken from them with unscrupulous legalitv by treaties ratified by congress and signed bv the government. These were called treaties, but were considered by many Indians little more than real-estate deals. From 1778 to 1868 , In ninety vears, there were 370 of these treatles slgned by the federal nation with the Indian nations. There were so many treaties, not because there were so many Indian wars, but because there were so many Indian lands, that the tribes were forced or enticed to 31 gn away. 9

In 1858, Indian Commissioner Charles E. Mix estimated the number of Indlans to be 350,000 . He further estimated that about 393 treatles between the Unfted States Government and the Indians had been signed since the adoption of the Constitution, and that approximately $581,163,188$ acres had been acquired through cessation at a cost of $\$ 49,816,344,10$

Indian clalms Commission. It is incredible that after nearly two hundred years of treaty relations with the federal nation, the Indian treaty issues required another major plece of federal legislation to absolve these treaty issues. Congress passed the Indian Clafms Commission Act to hear and determine the many unsettled Indian tribal clalms against the United States which arose before 1946. The president signed the bill into law on August 13,1946.11 The act superseded a law passed In 1863 when various tribes were at war with the Unfted States, which forbade Indians to sue in the Court of Clalms. Unt 1 the passage of the Indian Clalms Commission Act, the Indians 
could bring no claim against the government without a special act of Congress. The significance of the establishment of the Indian Clafms Commission derives from the fact that the government recognized claims and gave jurisdiction to the Commission in areas not comprehended under existing law or previous practice. A number of early Indian treatles with the United States Government remain in legal litigation in the federal courts today. Three hundred and seventy claims were originally filed in the Indian Claims Commission. By 1968, twenty-two years after the Indian Claims Commission had been authorized, less than half of the dockets had been settled.12

Indians as a Problem in the Territorial Struggle over Land. Seen as obstacles in the path of settlement and industrialfzation, the Indians became the "problem" in the struggle for territorial claims to the land. The solution for early settlers was the cry for battle. The aboriginal peoples were depicted as resistors to civilization and thus were dealt with accordingly.

The practice of European conquest and civilization of peoples guided the relationship of the early American settlers and the aboriginal natives. Early American history is dotted with Indian wars, the climactic acts of territorial conquest.

Decline in Indian Population. Indian population was decimated by wars. Bahr, Chadwick, and Day, In Native Amerlcans Today, estimate the Indian population within the current boundaries of the Unfted States in 1492 range from 700,000 to 1 
million. By 1871, when the Indians became officlal wards of the nation, thefr numbers had been reduced by the most radical forms of discrimination, war, and genoctde, to less than half a milion. Further population decline occurred under the early reservation system. The Indian population reached a low point of approximately 240,000 persons during the first few years after 1900.13

The following official census figures for Indians in the United States reflect population trends since 1890.14

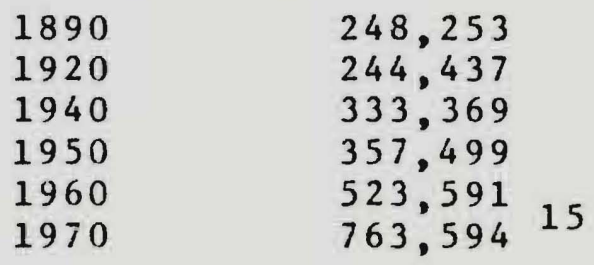

The lowest point of Indian population followed the era of Indian wars in America.

Early U. S. Indian Policy. The establishment of relations of the United States with the Indians generally have been through administrative agencies and it 18 therefore important to exame the structure, guiding policy, and manner of functioning of these agencles at varlous times. As a general rule, the English Crown and the colonies regulated relations between their own subjects and the Indians. 16

Prior to the adoption of the United States constitution, colonial ambassadors were appointed with the duties that consisted of observing events, negotiating treaties, and generally keeping peace between Indians and the settlers.17 on July 12 , 1775, the Continental Congress exercised definite governmental power for all the colonies, and declared its jurisdiction over 
Indian tribes.18 on August 7, 1789, early in the first Congress, the War Department was established, and the Secretary of the Department was entrusted with all matters relative to Indian affairs. 19 Relations between the United States Government and the Indians remained in the jurisdiction of the War Department unt 11 1824, when Secretary of War Calhoun created the Bureau of Indian Affairs by order of March $11,1824.20$

Indian Reservations. The reservation system was established following the creation of the Bureau of Indian Affairs in 1824 , and throughout the course of the eariy years was almed primarliy towards the removal of the Indians from their aboriginal territories and to the segregation of the Indian from the settlers.

It was not unt 11849 that the Bureau of Indian Affairs passed from military to civilian control. 21

The question of status of the Indian and the technique by which he might be civilized had not been answered satisfactorily in 1851 when Indian Commissioner Luke Lea wrote:

On the general subject of the civilization of the Indians, many and diversifled opinions have been put forth; but unfortunately, like the race to which they relate, they are too wild to be of much utility. The great question. How shall the Indians be civilized? yet remalns without a satisfactory answer. The magnitude of the subject, and the manifold difficulties inseparably connected with it, seem to have bewildered the minds of those who have attempted to give it the most thorough investigation. . I therefore leave the subject for the present, remarking only, that any plan for the civilization of our Indians will, in my fudgement, be fatally defective, if it does not provide, in the most efficlent manner, first, for their 
concentration; secondly, for their domestication;

and thirdly, for their ultimate incorporation into

the great body of our citizen population. 22

Government Policy for Indian Reservations. The government of American Indians living on reservations is the product of literally thousands of treaties, federal laws, and judicfal decisions, and a myrlad of rules and regulations issued by the government over the past 150 years. Presently the Bureau of Indian Affairs is organized to serve the 462,000 reservation Indians. 23 Indian trust land designated as reservations is tax-free and the federal government is charged with the responsibility of providing educational, health, and social services for the welfare of the reservation Indians. The federal government reserves the right to veto all tribal laws, codes, ordinances, and financial arrangements by empowering the Secretary of the Interior to regulate the administration of federal programs for Indians, a mandate which the federal officials exercise with great diligence.

Termination Policy. The constant fluctuating changes of American soclety's attitudes towards the Indian has generated a whole new set of problems far the Indian of today that affects the lives of not only the reservation Indian, but his tribesmen who reside in urban areas. Disregarding the long history of dependency that was forced upon reservation Indians and the depletion of tribal resources following World War II, Congress, with the support of officials administering Indian programs In the executive agencies, released the government from responsibility for Indians by terminating federal responsibility. 24 
In 1953, Congress passed a resolution (House Concurrent Resolution 108), calling for termination of federal supervision of reservations in five states and seven additional locations. 25 In all, ten thousand Indians from the states of Western oregon, Wisconsin, and Utah were terminated by this resolution before the Indian tribes could put a halt to the termination policy through appeals and suits in the courts. Termination activity by the federal government was halted, but only after several millions of acres of Indian land was lost and the Indians themselves released from federal responsibility.

President Nixon halted termination policy in 1970, by announcing administration policy repudiating the termination policy adopted by Congress in 1953.26

Indian Migration to Urban Areas. The environment on the reservation has constraints too strong for many of the residents, and migration away from the reservations began with the advent of World War II. 27 The Bureau of Indian Affalrs estimates that In the decade preceding 1972, 200,000 Indian people moved to urban areas.

Relocation Program. Over half of these migrants came on their own, the remainder were assisted in some way by the Bureau of Indian Affairs programs such as the Relocation Program initiated by the government in 1947 , to assist Hop 1 and Navajo Indians to seek employment opportunities in the urban centers of Los Angeles, Denver, Phoenix, and Salt Lake City. A national program of relocation assistance was undertaken in 1952 and 
expanded in 1957. Final expansion of the relocation program came about in 1962 to include job placement on or near reservations, as well as metropolitan areas and to acquire training to Increase employability. The major goals of the Employment Assistance Program are:

1. Develop employment opportunities for Indian people with some degree of skill who are employable but unable to find jobs.

2. Make avallable institutional training for all Indian boarding school and public school graduates who do not plan to or cannot go on to higher education.

3. Provide on-the-job training for the unskilled to meet the labor demands of the increased industrial development occurring on or near Indian reservations.

4. Provide vocational counseling and guidance to the unemployed or the underemployed reservation Indians.

5. Participate in communtty development programs on the reservation and provide work orlentation and motivation. 28

There is debate among Indian leaders and government officials as to the success or fallure of the relocation programs. The main purposes of the relocation program is to reduce the level of surplus labor on the reservation, in addition to improving the standard of living of the participants. The principle reasons for fallures that occur is because the programs are operated on such a small scale that major impact cannot be made. 29

Federal Relationships of Urban Indians. Government policy on the Indian residing in an urban area is virtually non-existent. The Bureau of Indian Affairs' responsibility does not extend to 
Indlans who have left the reservation. 30 The City Club of Portland, In a bulletin published in 1975, concluded that the Indian has no peculiar legal status as distinct from an Indian who resides on a reservation; and furthermore, that the urban Indian has qualified for very little special service from the federal government in terms of general welfare monies, housing assistance, job training, and education, since these benefits are tled almost entirely to reservation residence; and finally, that the new federal programs that do exist for urban Indians are transitional in nature, primarily designed to meet the needs of short-term job training, employment referral, emergency health care and emergency housing assistance.

Lukaczer, In The Indian Historlan, writes that not all American Indians are federally-recognized. 31 His figures show that 500,000 of the more than 800,000 Indians who are counted as Indians, Eskimo, and Aleuts, are federally-recognized Indians. The remaining more than 300,000 are non-federally-recognized. These are individuals who identify themselves as being "Indians" to census enumerators, or who are regarded as Indians in their communities. They live on reservations, in rural non-reservation areas, and in towns and cities throughout the United states. These Individuals represent significant sizes in some states and generally recelve no services as Indians. Many of these Individuals are in reality enrolled members of a federallyrecognized tribe, but because they do not reside on their respective reservations, they are designated as "Ineligible" for 
any federally-allocated Indian services. They are, in a sense, being jeopardized for joining the malnstream of American life.

In an editorial published by an Indian newspaper,

WASSAJA, commentary was made on a new issue facing the urban

Indian.32 A recent development in Indian policy that has been

In legislation for the past several years, the Indian Self-

Determination and Education Act, was signed into law on January

4, 1975. As enacted, the b111 (S 1017) is described as follows:

Public Law 93-683 contalns a congressional policy declaration. First, a Federal obligation to be responsive to the principle of self-determination through Indian involvement, participation, and direction of educational and service programs. Second, a Federal commitment, based on the unique Federal-Indian relationship to foster and encourage Indian self-determination through Indian participation in those programs and services which affect them. Third, a major national goal to provide educational services and opportunities which will enable Indians to compete and excel in the life areas of their choice.

The Implications of the b111 as 1t relates to the urban Indian is being closely examined by these groups. The bill represents a sense of deep disappointment for this particular group of Indians. The reason for the anxiety of the urban Indian population is that the Act makes it obligatory for the urban Indian projects to obtain sanction from an Indian tribe in order to be eliglble for funding from such agencies as Indian Health Service. Other profects will be similarly affected. Funding sources such as CETA (Comprehensive Employment Act), Title IV (Indian Education Act), and EDA (Economic Development Administration) are not so affected, so far. As interpreted by the urban Indian population, the bill pushes them even farther away from any fair opportunity to 
compete for funds from the federal government that are allocated for Indian services, and at the same time the interpretations of the bill cause the urban Indian population to be put in the position of mistrust by the reservation population.

Service Needs of Urban Indians

Research of literature on the urban Indian presents a disappointing amount of theoretical works, 33 relative to what this author believes may be some of the primary motivating factors that cause Indians to migrate from the reservations to the urban centers. Some of these factors are:

economic deprivation

poor health care educational discrimination ethnic discrimination cultural discrimination

The bulk of empirical studies on the urban Indian are presented as masters theses and doctoral dissertations. 34 The empirical studies on the urban Indian that have been presented examine the fields of human dynamics, such as

$$
\text { assimilation }
$$

acculturation

adjustment

adaptation

Steele, in American Indians and Urban Life, states that 
only since about 1960 have urban Indians began to attract the attention of the social scientist. 35

It is the opinion of the author that the bulk of the studies was presented by non-Indian writers, and research of available literature on the urban Indian revealed that to be the case.

Delorla, in Native Americans Today, states:

United States Department of Health, Education, and Welfare gave out $\$ 10$ million last year (1968) to nonIndians to study Indians. Not one single dollar went to an Indian scholar or researcher to present the point of view of Indian people. And the studies done by nonIndians added nothing to what was already known about Ind Ians. 36

Comments by Deloria in God is Red presents a contrast of the incongrufty of some of the published works on Indians in general. His point is that non-Indian writers could not concelvably possess any information that would be relevant to the formation of Indian policy. 37

Avallable literature on Indians focuses on the early history of the relations between Indians and the dominant society; the development of Indian policy throughout the years; and the circumstances of the present-day Indian who resides on the reservation and in urban areas. Very little empirical study is avallable on the human service needs of Indians as they enter urban centers.

Major attention has been given to the economic status of the urban Indian and to a lesser degree, to the health status of these Indians in the urban areas, primarily the study of alcoholism and its effects on the urban Indian. Bahr writes, 
In Native Americans today:

One consequence of this research gap is an ignorance that impedes the planning and execution of programs almed at ameliorating many of the negative consequences of urban migration. 38

Bahr also writes:

Textbooks tend to reflect the dominant interests of professional academicians. Hence, they have ignored the urban Indian. 39

and finally, Bahr states:

Moreover, the urban Indian is not particularly good journalistic copy. Lacking headdress and beads, he seems 'just like anybody else' and attracts no speclal attention. Besides, the unspoken argument goes, he lacks a future. The urban Indian is on his way to assimilation, is a 'vanishing Native American,' and to study him in the city is to catch him 'In process' between identities and in fact neither traditional native American nor assimilated modern man, so what have you? Conceptually hard to define, lacking human interest (now, if only he would rlot or liberate some federal property . . . ), not clustered for ready observability, and not posing a particular problem for anyone (his problems tend to be his own, since to a great extent he hasn't known how to 'lean on' clty bureaucracies to make his problem theirs, as stated by Ablon in Phylon, 26, (Winter 1965), p. 370), 40 the Native American in the city has been a stranger, his Influence diminished by his invisibility to the public, and his plight (whatever it is) accorded a low priority by city, state, and federal agencies.41

Bahr's comments generally are relevant. He also provides a good example of out-dated and unavallable literature on what's happening with Indians in the mid-70's.

Bahr's emphasis in parenthesis "(now if only he would riot or liberate some federal property... )" is a good example of out-dated information. The reservation Indian of today and his urban brothers, advocates of "Red Power" have adopted the Increasing milftancy of repressed minorities in seeking greater 
freedom and self-determination for themselves. Manffestations of this newly-aroused sentiment include Indian occupation of former federal institutions, such as Alcatraz Island, California, the seizure of Ellis Island, New York, and the march on Fort Lewis, washington. 42

To keep up with what is happening in the Indian world, the researcher needs to seek material from contemporary published works, mostly in the form of Indian newspapers, 11ke WASSAJA, 43 a national newspaper of Indian America, and AWKWASASNE NOTES, 44 official publication of the Mohawk Nation at Awkwasasne, near Hogansburg, New York, and the Indian Historian. 45

Data on Human Service Needs of Urban Indians. Avallable data on the human service needs of urban Indians is mostly in the form of unpublished studies on Indians residing in urban centers, 1ike Los Angeles, San Francisco, and Portland. 48 The studies deal primarily with assessment of needs for health care. A communty survey report on the human service needs of Indians residing in Portland, Oregon, was done by Grant-Morgan Association of Portland, oregon in 1972.49 The study was developed in preparation for application to the federal government for funds to expand exfsting facilities in Portland, to serve the human service needs of Indians residing there. Findings of the study reveal these specific problem areas regarding Indians in the community, ranked in order of need:

Housing

Health care

Food and nutrition 
Education

Employment

A 1 cohol $18 \mathrm{~m} /$ Drugs

Cultural Identity

other: such areas as halfway houses

for convicts, ch1ld day-care

centers, transportation, and

child-care, prejudice of law-

enforcement, young people in

ja11, and employment training. 50

The City Club of Portland Bulletin on October 27, 1975, stated:

The Grant Morgan Associates, The Urban Indian in Multnomah County, Oregon--A Commity Survey (1972).'

This report, commissioned by the Urban Indian Program, 1s one of the most valuable sources of information on Indians in Portland, and was extensively relied upon by the Urban Indlan Program in preparing the structure of 1 ts approach to the problems of Indians living in Portland. 51

Summary. The lack of relevant data on the human service needs of the urban Indian seems to support Deloria's and Bahr's conclusions that there is a noticeable lack of pertinent information avallable on this particular group of people, and attempts to assess the needs of this urban population can only be determined by estimating needs in terms of limited data that is avallable. To refterate, the needs are there, but no one has sald so in any specific terms. 


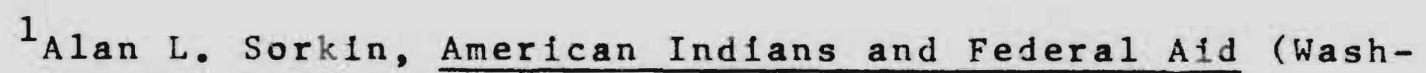
ington, D. C.: The Brookings Institute, 1971), p. 19.

2 Vine Deloria, Jr., fod Is Red (New York: Dell Publishing Company, Inc., 1973), pp. $\frac{\text {, }}{39-56}$

${ }^{3}$ Howard M. Bahr, Bruce A. Chadwlck, and Robert C. Day, Native Americans Today: Sociological Perspectives (New York: Harper \& Row, Publishers, 1972), P. 48 .

${ }^{4}$ Peter Farb, Man's Rise to Civilization (Dutton, New York: 1968), p. 299 .

${ }^{5}$ Deloria, o․ 도., p. 43 .

${ }^{6}$ Ernest C. Downs, "How the East Was Lost," American Indian Journal (Washington, D. C.: Institute for the Development of Indian Law, 1975), pp. 6-10.

\section{Ibid.}

${ }^{8}$ Felix S. Cohen, Handbook of Federal Indian Law (Washington, D. C.: U. S. Government Printing Office, 1945), pp. 17-18.

${ }^{9}$ Stan Steiner, The New Indians (New York: Dell PublishIng Co., 1968), p. 16

${ }^{10}$ Felix s. Cohen, op. c1t., p. 15 .

$11_{\text {Wilcomb E. Washburn, Red Man's Land--White Man's Law }}$

(New York: Charles Scribner's Sons, 1971), pp. 102-103.

12 vine Delor 1a, Jr., Behind the Trail of Broken Treaties

(New York: Dell Publishing Co., Inc., 1974), p. 225.

13 Bahr, Chadwick, Day, op. cit., p. 43.

${ }^{14} \mathrm{Ib1d}$. 
15 Helen W. Johnson, American Indians in Transition (WashIngton, D. C.: Economic Development Division, Economic Research Service, U. S. Dept. of Agriculture, Agricultural Economic Report No. 283, Apr11, 1973), p. 3.

${ }^{16}$ Cohen, op. cit., p. 9 .

17 Ibld.

18 Ib1d.

${ }^{19}$ Ib1d.

${ }^{20}$ Ib1d., P. 10.

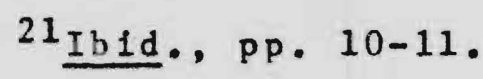

22 Ib1d., p. 14 .

${ }^{23}$ Alvin M. Josephy, Red Power (New York: American Heritage Press, 1971), p. 224.

${ }^{24}$ California Indian Legal Service pamphlet, An Explanation of Termination (Berkeley: 1968).

25

Sar A. Levitan and Barbara Hetrick, B1g Brothers Indian Programs--With Reservations (New York: McGraw-H111, Inc., 1971), PP. 17-19.

${ }^{26}$ Ib1d., P. 18 .

27Alan L. Sorkin, op. c1t., Pp. 104-105.

${ }^{28}$ Howard M. Bahr, Chadwick and Day, op. c1t., Pp. 407-409.

29 Ib1d., p. 474 .

30 Josephy, op. c1t., Red Power, p. 224.

31 Moses Lukaczer, The Indian Historian (San Francisco: Published Quarterly by the American Indian Historical Society, Winter, 1974), Vol. 7, No. 1, p. 18.

${ }^{32}$ Editorial in the WASSAJA. The National Newspaper of Indian America, published by the American Indian Historical Society, San Francisco, California. 
33Alonzo T. Spang, Jr., Geographic Mobility of Indians: Indianess, Work Preparation, and Geographlc Mobllity of Reservation and Urban Indians, Doctoral Dissertation, Ar 1 zona State University, January, 1973, pp. 6-10.

${ }^{34}$ Ibid.

${ }^{35}$ Charles Hoy Steele, American Indians and Urban Life: A Community Study, Doctoral Dissertation, Department of American Studies, University of Kansas, 1972, pp. 3-8.

36 Deloria, Native Americans Today, op. cit., p. 506.
${ }^{37}$ Deloria, God Is Red, op. cit., pp. $44-56$.
38 Bahr, Day and Chadwick, op. cit., p. 406.
39 Ibid.
40 Joan Ablon, "American Indian Relocation: Problems of Dependency and Management in the City," PHYLON, 26 (Winter, $1965)$, p. 370 .

$41_{\mathrm{Bahr}}$, Day and Chadw1ck, op. c1t., p. 407.

${ }^{42}$ Levitan and Hetrick, op. cit., p. 4.

43 WASSASSJA: The National Newspaper of Indian America, published by the American Indian Historical Society, San Francisco, California.

44 AWKWASASNE NOTES: Published by the Program in American Studies of the State University of New York at Buffalo,

${ }^{45}$ The Indian Historlan, published by the Amerfcan Historical Society, San Francisco, California, Winter, 1974, Vol. 7 , No. 1 .

46Paul Torrens, The Health Problems Among Native Americans in Central Los Angeles, an unpublished report: U.C.L.A., Los Angeles, Calif., Winter, 1974.

${ }^{47}$ Michael Fuchs, A Study of Health Care Patterns Among Native Americans in the San Francisco Bay Area, an unpublished report, San Franc1sco, California, January, 1974. 
${ }^{48}$ Dale Hoffland and John Lofland, The Closing Circle: The Study of a Developing Urban Indian Health Center, unpub11shed report, June, 1974 .

${ }^{49}$ Grant Morgan and Associates, The Urban Indian in Multnomah County, Oregon, Portland: Grant Morgan Corp., November, 1972 .

50 Grant Morgan and Associates: Urban Indian Planning Survey, Portland: Grant Morgan Corp., November, 1972.

${ }^{51}$ City Club of Portland Bulletin, Published each Friday by the City Club of Portland, Oregon, Vol. 56, No. 22, October 27,1975, p. 70 . 
CHAPTER III

DESCRIPTIONS OF LOCAL SYSTEMS

In relation to looking at the service needs of Indians in Portland, investigation revealed the existence of several social service agencies in the area. An overview is presented here to relate the functions of these agencies.

Urban Indian Program

The Urban Indian Program (UIP) began operations on May 1 , 1972, under contract between the Portland Metropolitan Steering Committee and the Unfted Indian Council, Inc. Ordinance number 137547 was passed by the City Counc1l November 28, 1973, authorizing an agreement with Urban Indian Council to provide services to Native Americans.

The Urban Indian Program serves as a port of entry for Indians coming into the portland area. The center helps resident Indians to cope more effectively with the urban environment, and in doing so, to maintain their Indian identity.

The objectives of the program are:

1. To increase the accessibility of existing resources to the City's Indian population through an Urban Indian Program.

2. To develop health services supplementing those presently available which do not allow for special needs in the Indian population. 
3. To maximfze the impact of resources avaliable to the program.

4. To utilize community input in the planning of services delivery.

5. To provide a cultural and human services focal point for Portland's Indian community in an urban Indian center. 1

The program presently provides these services:

1. Outreach support in finding housing, food, clothing, and other basic necessities;

2. Health services such as immunizations, tuberculosis screening, home care, well-child clinics, and health referrals;

3. Counseling;

4. Employment assistance, including job development and trainfing;

5. Legal Assistance;

6. Pre-school day care services for children whose parents are working, in school or in training programs.

The program endeavors to create a complete Indian Center, combining both social services and a variety of Indian cultural activities. 2

Bureau of Indian Affairs

The Bureau of Indian Affairs (BIA, United States Department of the Interior, maintains a regional center in Portland, 
known as the Portland Area Office. The Portland Area office has furisdiction over Indians who live on reservations in Idaho, Oregon, and Washington. Generally, the BIA is entrusted with the responsibility of administering all matters pertaining to Indian Affairs. The Bureau provides many of the services that non-Indians recelve from state and local government. Each of its functions, such as social services, education, and industrial development, is the responsibility of an assistant commissioner. Most federal services provided under the BIA to reservation Indians are based on the Snyder Act of 1921 , which directs the expenditure of funds appropriated thereunder, ". for the benefit, care, and assistance of Indians throughout the United States.." 3

The primary responsibility of the Portland Area office is the administration of Indian Programs in its area of jurisdiction: the Indian reservations in Idaho, Oregon, and Washington. The BIA's responsibility does not extend to Indians who have left reservations. ${ }^{4}$ Thus, the Portland Area office has little to offer to the Indians who reside in Portland. Their services are extended mostly to the participants in adult vocational training and employment assistance programs.

Indian Health Services

The Indian Health Services (IHS), United States Department of Health, Education, and Welfare, Public Health Services, maintains regional offices in Portland. Through health facilities, 
the Portland Area office provides direct health services to Indian groups who reside on or near reservations in the states of Idaho, Oregon, and Washington. The area is divided into twelve Service Units within the area of its furisdiction. The goals of the Indian Health Program are:

1. Assists Indian tribes in developing their capacity to man and manage their health programs through activities, including health and management training, technical assistance, and human resource development;

2. Facilitates and assists Indian tribes in coordinating health planning, in obtaining and utilizing health resources avaliable through federal, state, and local programs, in operation of comprehensive health programs, and in health program evaluations;

3. Provides comprehensive health care services, including hospital and ambulatory medical care, preventive and rehabilitative services, and development of community sanitary facilities;

4. Serves as the principle federal advocate for Indians in the health field to assure comprehensive health services for American Indians and Alaskan natives. 5

The Portland office offers little in the way of direct services to the Indians who reside there. Their services are limited to the Indians who are participants in the BIA adult 
vocational training and employment assistance programs. Additionally, the Portland office assists some Indians who are in the area for medical care and to some Indians who attend educational institutions in the area. Medical services are generally not offered to the more permanent Indian residents of the area.

Native American Rehabilitation Association

The Native American Rehabilitation Association (NARA) is the sponsoring agency for the treatment of alcoholism among Indians in the Portland area. The association maintains Service Centers for the treatment of alcoholism.

The overall objective of the program is to work with Indian alcoholics and their families to help establish and maintain sobriety through these activities: reduce abuse drinking; improve job performance and stablitty; improve nutrition and general health; improve personal, family, and communty relationships; and develop interest in basic vocational and academic areas. Program services of NARA are available to Indians of the area with identifiable alcoholism problems.

other Groups

Portland American Indian Center (PAIC) is the oldest (1959) and largest single Indian organization in Portland. Its activities are conducted by a board of directors and it maintains a center where emergency provisions are available. 
It frequently sponsors Indian festivals in the Portland area. 6

United Minority Workers is a multi-raclal organization, including Indians, that serves as an advocacy organization for employment opportunities, particularly in the construction industry. 7

\section{SUMMARY}

As can be seen from this overview, the service needs of many Indians in the Portland area are primarlly being served through the Urban Indian Program. There seems to be evidence that Indians do not fully ut 11 ize services the other private, clty, state and federal agencles provide. 


\section{CHAPTER III}

\section{FOOTNOTES}

${ }^{1}$ progress Report, Urban Indian Program, prepared by the City of Portland Human Resources Bureau, Program Operation Division, Evaluation Unit, Portland, Oregon, May 20, 1974, preface, pp. Iv-v.

${ }^{2}$ City Club of Portland Bulletin, Published by the City Club of Portland, Oregon, Vol. 56, No. 22, October 26, 1975 . P. $52-53$.

${ }^{3}$ Ib1d., P. 51 .

${ }^{4} \mathrm{Josephy,} \mathrm{op}$. c1t., p. 224.

${ }^{5}$ Indian Health, a pamphlet prepared by the U. S. Dept. of Health, Education, and Welfare,

${ }^{6}$ City Club of Portland Bulletin, op. c1t.. p. 53.

7 Ib Id. 


\section{CHAPTER IV}

\section{METHODOLOGY: DESIGN AND PROCEDURE}

This study was developed to explore the profile of Indians who reside in Portland, where they came from, why they came to Portland, and what their needs were when they came to Portland. Additionally, the study explored the quality of services provided by the existing facility in Portland, the Urban Indian Program, which is designated as the social service agency and the cultural center for Indians who reside there. The interview schedule was developed and pre-tested. Simple random sampling was used in the selection of sampling unfts. These sampling units were selected from the following agencies and organizations: Urban Indian Program, Bureau of Indian Affairs, Indian Health Services, and Alaska Native Association of oregon.

Sampling was achleved by selecting units at specific intervals until a total number of seventy was selected. Records were accepted as a part of the sample if: the birth date was after Apr11 5, 1956 (age 18), the residence was established in the city limits of Portland, and the service application date was recorded by Apr1l 5, 1974.

An interview schedule was developed and pre-tested.

A letter of Introduction was malled to each of the seventy subjects selected in the sampling. The introductory 
letter explained what the study was about and how the subject's name had been selected. The letter also introduced the interviewer.

The interview schedule was administered to thirty subjects by personal interview, mostly in their homes. Time consumed for the interview ranged from one hour to four hours. The entire survey covered a period of approximately four weeks. Thirty interviews were completed and forty were unable to be completed for the following reasons: eleven of the letters of introduction were returned from the United states Postal Service dead letter office in San Francisco, California; nineteen of the subfects moved out of Portland and left no forwarding address; ten were unable to be reached either by telephone or in person.

Limftations in gathering the data resulted from the difficulty in attempts to locate over half of the subjects. Numerous return trips were made to a subject's listed address, only to find that the subject no longer resided there and had not filed a change of address.

The study also was limited by the fact that the principal investigator worked alone and conducted all of the interviews, in addition to identifying sampling units and developing the interview schedule. 
CHAPTER V

FINDINGS

The findings of the study are presented in two parts. The first part reveals the characteristics of the tribal profile of the group interviewed, where these subjects came from, and why they came to Portland; and the second part reveals the respondents' opinion of the quality of services provided by the Urban Indian Program.

Characteristics of the Tribal Profile

of the thirty subjects interviewed, tribal identity was represented by twenty-eight different Indian tribal groups; either in degrees of full-blood, or by combinations of mixed tribal groups, or by combinations of Indian/white, or by combinations of Indian/negro, and lastly, by combinations of Indian/Chicano. Ten of the subjects were full-blood Indian; six were one-half Indian; and the remalning sixteen of the thirty subjects interviewed were less than one-half degree Indian blood. Since tribal enrollment with an Indian group may be a determinant factor in the question of being Indian, response was evoked concerning the subject's enrollment status. of the thirty interviewed, twenty-elght are enrolled as members of a federally-recognized tribal group. The two who indicated no enrollment status responded by explaining why they are not enrolled. The two reasons given were: one informal adoption; one lost or unknown family record and not possessing knowledge 
or resources to investigate the matter. Fourteen of the thirty subjects were under the age of twenty-six years, and the remaining sixteen ranged in age from twenty-six to fiftyfive years. Of the nineteen females and eleven males interviewed: twelve were married, elght were single, three were separated, and three indicated common-law living arrangements. One of the thirty subjects indicated their household consisted of ten or more members, two indicated nine or more members, three indicated seven or more members, nine indicated five or more members, twelve indicated three or more members, and three indicated single households. Of the thirty subjects interviewed, eleven indicated some college, four possess college degrees, seven are high school graduates, six completed funior high school, and two completed elementary school. Seventeen of the thirty subjects are employed, with two of these indicating itinerant employment and fifteen are unemployed. Twenty-five indicated means of income other than earned income. Some of the other means of income reported were: social security retirement and disability pension; public assistance; Bureau of Indian Affalrs Assistance, mostly in the form of financial assistance during vocational training and fob placement; and tribal income from sources such as reservation property leases, reservation resource income (per capital payments) and land claims settlement from the federal government. Income ranged from fourteen with yearly income of less than three thousand dollars to two who reported income 
over fifteen thousand dollars. Years of employment range from two who have been employed steadily for more than fifteen years, and at the opposite range four have been employed for four months.

These characteristics present a profile that is diverse, keeping in mind that close to half are under the age of twentysix and nearly half of the thirty subjects have income of less than three thousand dollars a year.

of the Indians interviewed, it appears that many are younger Indians, and are in the lower income category. Restating that other sources of income indicated showed income from Bureau of Indian Affairs job placement and vocational training, this younger age bracket may indicate an Indian population that may be transient in nature.

Where The Subjects Came From and Why They Came to Portland

The determination of where the subjects came from before they came to Portland indicated twenty were born and reared on a reservation and the remaining ten were born and reared in urban areas, towns near a reservation, and in the case of Alaska Nations, in Indian Villages and urban areas of Alaska. The subfects indicated they left the reservations for reasons such as: education and employment (which recelved the highest degree of response), relocation by the Bureau of Indian Affairs to urban areas (usually for job placement and vocational training), pressure from friends; pressure from town and reservation police; dissatisfaction with the Bureau of Indian Affairs; equal opportunity; marrlage; college; and 
to meet new friends.

The subjects indicated their needs when they entered Portland to be: money and jobs as the biggest need; next were health care, transportation, food, friends, legal help, child day-care services, and lastly, clothing.

The Quality of Service

In probing for response to the quality of services provided through the Urban Indian Program, the interview schedule was divided into sections on the components of the agency. They are as follows: outreach services; health center; counseling services; employment center; legal services; and the child pre-school and day-care center.

Outreach services help find housing, food, clothing, and other necessities of life in the Metropolitan Area. This component serves as an advocate for those who need help. Twelve of the thirty subjects indicated use of these services, and also listed using the outreach component for other services such as: advising in relation to reservation ties like family, business and legal assistance. Six of the users indicated "full satisfaction" with the services provided, five indicated "satisfaction" with the services, and one indicated a "neutral" response, as no feeling about the service one way or another. One indicated "not very satisfled" with the services provided. Quality of the staff delivery system indicated seven of the users were treated "very good" by the staff, four indicated they were treated "good," and one indicated "average" treatment 
was received. The users in general are pleased that there is an outreach service available to Indians in Portland and also that the program is being administered primarily by Indian staff.

The health center provides health and dental clinics, limited home care, well-child clinics, transportation, and referral to existing health care facilities. Fifteen of the thirty subjects interviewed indicated use of health services. Six of the users indicated "full satisfaction" with services provided, five indicated "satisfaction" with the services, two gave "neutral" response, as no feeling about the service one way or another, and two indicated they were "not satisfied" with the service. The quality of the staff delivery system indicated eleven of the users were treated "very good" by the staff, two indicated they were treated "good" and one indicated "average" treatment was received. The users stated they were pleased with the health center and that free medical care is avallable there when needed. Again, respondents' satisfaction was shown that the health center is staffed with Indian people.

The counseling component helps Indians to live as Indians in the city, provides alcohol and drug abuse counseling, provides access to all Indian alcoholism programs and Indian retreat camp. Nine of the thirty subjects interviewed ind $1-$ cated use of the counseling component. Four of the users indicated "full satisfaction" with services provided, four indicated "satisfaction" with the services, and one indicated 
a "neutral" response as no feeling, one way or another.

Five of the users reported that they were treated "very good" by the staff, one was treated "good," one indicated "average" treatment was received, and one indicated "not good" service was received. Again, general satisfaction with the service was indicated by the users. The respondents who ind $1-$ cated average and below average treatment received from the staff commented that the counseling staff needed more training in interviewing techniques and treatment methods.

The employment center assists Indians in finding and becoming qualified for the jobs they want through fob and vocational training. Ten of the thirty subjects interviewed were users. Two indicated "full satisfaction" with the services provided, three indicated "satisfaction", one indicated a "neutral" response, and two Indicated "not satisfied" with the services, and two indicated "very dissatisfled" with the services provided. Two of the respondents reported they were treated "very good" by the staff, one reported "good" treatment, five indicated they recelved "average" treatment by the staff, one indicated "not satisfled" with services provided, and one Indicated "dissatisfaction" with services provided. The respondents who indicated dissatisfaction with the services states their reasons as: staff not following through with fob applications and fob placement; and also staff not providing adequate counseling when fob placement did not occur. Here again, the respondents suggested more staff training in interview techniques and in employment counseling. 
The legal assistance component provides access to legal help for those with elther civil or criminal legal problems. Six of the thirty subjects interviewed were users of the legal assistance components for reasons such as: clvil problems, fail, civil rights, divorce and reservation legal issues. Three of the users indicated "full satisfaction" with services provided, one indicated "satisfaction" with the services, one Indfcated an "average" response, as no feeling one way or another, and one was "not satisfied" with the services. Two of the respondents reported they were treated "very good" by the staff, three reported they were treated "good," and one reported "poor" treatment. The respondent who indicated "average" and "below average" treatment gave the following reason for the response: staff not following through on legal assistance referral and counseling service. The respondents' suggestions were that the staff needed to be more aware of the laws with special emphasis on the civil rights of Indians and the status of Indians in relation to state and federal laws. Child pre-school and day-care center, E-Kosh-Kosh: provides care for children whose parents are working, attending school, or are in training programs. Elght of the thirty subjects interviewed were users of the day-care center. Seven indicated they were "fully satisfled" with the services provided, and one indicated they were "satisfied" with the services. Six reported they were treated "very good" by the staff, one reported they were treated "good" by the staff, and 
one indicated an "average" treatment by the staff. A high degree of satisfaction was reported by the users mainly for the reason of the structure of the program relative to the child's learning experiences in Indian culture. The users also Indicated satisfaction with the staff and the good care the children recelve at the facility. 


\section{CONCLUSION}

The data collected in the local area supports many of the points made in the historical review.

Indians in Portland generally present diverse Indian tribal affiliations. The group of thirty Indians who were interviewed for this study represent twenty-eight different Indian tribes, efther by degrees of fullblood or combinations of mixed tribal groups or combinations with other races. The diversity of the tribal characteristics shows that Indians in Portland represent nearly all areas of the United States and Alaska.

The point to be made about tribal characteristics of the Indian in Portland is that they represent a wide range of tribal groups and that this characteristic of complex Indian identity is consistent with the concepts of mobility, in that many Indians of Portland came here from reservations. Some of the major reasons Indians left their reservations and came to Portland were because of the low economic conditions and the poor health standards there. The barriers to satisfactory living conditions on the reservation were shown by the group interviewed to be: poor federal control, the paternal1st1c attitude of the federal government towards the treatment of reservation Indians, and that generally not much is being done on the reservation to improve job opportunities there. Furthermore, the major reason Indians come to Portland 
Is to achieve satisfactory employment status and to improve their standard of health. To achieve these goals many Indians utilize the services of the local Indian Center, the Urban Indian Program, which is designed and managed by Indians, to assist them when they enter the area and to provide continuous support services after they have located here.

It should be stressed that the reservation Indian who moves to the city loses his U. S. Public Health Services medical and dental, his relatively inexpensive housing and transportation, food, clothing, and other essentials that may have been produced on the reservation. They also lose the protection of their family and kin group in time of need.

Conclusions on the quality of services provided by UIP generally is satisfactory. The exceptions were some degree of dissatisfaction with employment services because of poor staff management in fob counseling.

Generally the overall response, to the quality of services at UIP was that Indians are pleased that the agency is here and that it is being administered primarily by Indian staff.

Some of the arguments presented in the study are that control over Indian life has been dominated by the federal qovernment, mostly by non-Indian influence, and very little power has been offered the Indian in the control over his own life. This empirical study is small and more study can be done on the urban Indian in order to present more relevant and contemporary information on the situation of this group of Indians. 
This researcher recelved satisfactory response from the group studied and the respondents indicated pleasure in seeing an Indian doing the study. They also indicated more studies should be conducted by Indians, with the group of those who reside in urban areas, so that the Indian point of view can be represented more often.

The uniqueness of the American Indian has been evidenced through studies done by anthropologists and sociologists alike. As can be seen from the historical review presented in this study, the situation of the Indian's life shows that there is a set of diverse problems involving interrelationships of Indians and the dominant society in which they live, in a broad ecological and institutional context. Indians have tried to deal with their own problems by attempting to influence some control over their own lives, but many features of their present situations are beyond their control. 
BIBL IOGRAPHY

An Explanation of Termination, a pamphlet prepared and distributed by California Indian Legal Service (copyright) California Rural Legal Service, Berkeley, Calif., 1968.

AWKWASASNE NOTES, published by the Program in American Studies of the State University of New York at Buffalo,

Ablon, Joan. "American Indian Relocation: Problems of Dependency and Management in the City," PHYLON, 26, Winter, 1965.

Bahr, Howard M., Bruce A. Chadwlck, and Robert C. Day. Native Americans Today: Sociological Perspectives. New York: Harper \& Row, Publishers, 1972 .

Cohen, Felix S. Handbook of Federal Indian Law. Washington, D. C.: U. S. Government Printing Office, 1945.

City Club of Portland Bulletin. Published each Friday by the City Club of Portland, Oregon, Vol. 56, No. 22, october $27,1975$.

Deloria, Vine, Jr. God Is Red. New York: Dell Publishing Company, Inc., 1973 . - Behind the Trall of Broken Treaties. New York: De11 Publishing Company, Inc., 1974.

Downs, Ernest $C$. "How the East Was Lost," American Indian Journal. Washington, D. C.: Institute for the Development of Indian Law, 1975.

Farb, Peter. Man's Rise to Civilization. Dutton, New York: 1968.

Fuchs, Michael. A Study of Health Care Patterns Among Native Americans in the San Francisco Bay Area. An unpublished report, San Francisco, California, January, 1974.

Hoffland, Dale, and John Lofland. The Closing Circle: The Study of a Developing Urban Indian Health Center. Unpubl1shed report, June, 1974.

Johnson, Helen W. American Indians in Transition. Washington, D. C.: Economic Development Division, Economic Research Service, U. S. Department of Agriculture, Agricultural Economic Report No. 283, Apr11, 1973. 
Josephy, Alvin M. Red Power. New York: American Heritage Press, 1971.

Levitan, Sar A., and Barbara Hetrick. Big Brothers Indian Programs-With Reservations. New York: McGraw-H111, Inc., 1971.

Levine, Stuart, and Nancy 0. Lurie. The American Indian Today. Baltimore: Penguin Books, Inc., 1972.

Lukaczer, Moses. The Indian Historian. San Francisco: Published Quarterly by the American Indian Historical Society, Winter, 1974 .

Morgan, Grant, and Associates. The Urban Indian in Multnomah County, Oregon. Portland, Oregon: Grant Morgan Corp., November, 1972 .

Newman, William M. American Pleurism, A Study of Minority Groups and Soctal Theory. New York: Harper \& Row, Publishers, 1973 .

Sorkin, Alan L. American Indians and Federal Ald. Washington, D. C.: The Brookings Institute, 1971.

Spang, Alonzo T., Jr. Geographic Mobility of Indians: Indianess, Work Preparation, and Geographic Mobility of Reservation and Urban Indians. Doctoral Dissertation, Arizona State University, January, 1973.

Steele, Charles Hoy. American Indians and Urban Life: A Community Study. Doctoral Dissertation, Department of American Studies, University of Kansas, 1972.

Steiner, Stan. The New Indians. New York: Dell Publishing Company, 1968 .

The Indian Historian, published by the American Historical Soclety, San Francisco, California, Winter, 1974.

Torrens, Paul. The Health Problems Among Native Americans in Central Los Angeles, an unpublished report: U.C.L.A., Los Angeles, California, Winter, 1974.

Washburn, Wilcomb E. Red Man's Land--White Man's Law. New York: Charles scribner's Sons, 1971.

WASSASSJA: The National Newspaper of Indian America. Published by the American Indian Historical Society, San Francisco, California, 